\title{
Consequences of the energy policy in member states of the European Union - the renewable energy sources targets
}

ABSTRACT: The aim of the article is to discuss and assess the diversification of renewable energy sources consumption in European Union member states. The time scope covers 2005 and 2015. The data comes from Eurostat. The analysis was based on synthetic indicators - using a non-standard method. Synthetic indicators were assessed based on three simple features such as: the share of renewable energy in energy consumption in 2015 , the difference between the share of renewable energy in energy consumption in 2015 and in 2005 (in percentage points), deficit/surplus in the 2020 target reached in 2015 (in percentage points). The European Union member states were divided into four diversified group in terms of renewable energy sources consumption (first class - a very high level, second class - quite a high level, third class - quite a low level, fourth class - a very low level). Then the divided groups were analyzed according to the share of renewable energy sources in the primary production of renewable energy and the consumption of individual renewable energy sources. During the research period renewable energy consumption increased in the European Union, but individual member states are characterized by a diverse situation. The type of energy used depends largely on national resources. The countries of Northern Europe are characterized by a gre-

$\triangle$ Corresponding Author: Luiza Ossowska, e-mail: luiza.ossowska@tu.koszalin.pl

1 Faculty of Economic Sciences, Koszalin University of Technology, Poland, ORCID iD: 0000-0002-1572-8016; e-mail: luiza.ossowska@tu.koszalin.pl

2019. The Author(s). This is an open-access article distributed under the terms of the Creative Commons Attribution-ShareAlike International License (CC BY-SA 4.0, http://creativecommons.org/licenses/by-sa/4.0/), which permits use, distribution, and reproduction in any medium, provided that the Article is properly cited. 
ater share of renewable energy sources in consumption. Biomass is the most popular renewable source of energy in the European Union. Depending on the conditions of individual countries - it is agricultural and forest biomass.

KEYWORDS: energy policy, renewable energy, European Union countries

\section{Introduction}

According to the current energy policy the promotion of renewable energy sources is a priority in the European Union (EC 2011). The current energy policy framework was set at the European Union summit in Brussels in March 2007. The plan for the years 2007-2009 covered five priority directions concerning: the internal electricity and gas market, security of supply, rational use of renewable energy sources, development of new low-carbon technologies. At this summit the $3 \times 20$ targets were accepted by the European member states. These targets meant: reduction of $\mathrm{CO}_{2}$ emissions by $20 \%$ (compared to 1990), reduction of total primary energy consumption by $20 \%$ and the increase of renewable energy sources share in energy consumption by $20 \%$. The renewable energy resources target was indicated for the entire European Union area. Thus, member states have developed and implement their own national RES targets. These targets vary depending on the capabilities and conditions of individual member states (Pach-Gurgul 2014; Pach-Gurgul 2012; EC 2010; Miciuła 2015; Wojtkowska-Łodej 2014; Paska and Surma 2013; Kościk 2012).

According to the consequences of the European Union energy policy the aim of the research is to discuss and assess the diversification of renewable energy sources consumption in EU member states. The time scope covers 2005 and 2015.

\section{Literature review}

Fossil fuels pollute the environment. Renewable energy sources are alternative to conventional sources. In contrast to conventional fuels, renewable energy sources are ecological (Fridleifsson 2001; Panwar et al. 2011). Renewable energy sources are characterized by the rapid replenishment of resources. The use of renewable energy sources does not lead to the exhaustion of the resource and helps to reduce the emission of carbon dioxide and other harmful substances. (Ciechanowicz 1997). Moreover various renewable energy sources can be used: biomass, hydro, wind, biogas, solar or geothermal sources and many renewable energy technologies had been developed (Jabłoński and Wnuk 2009; Ijadi Maghsoodi et al. 2018). 
Replacing fossil fuels with renewables reduces the need of energy import, and consequently, countries' dependence on exporting. Renewable energy is produced from local natural resources that are constantly replenished and environmentally friendly. Thanks to this features renewables are available, accessible and acceptable worldwide (Gökgöz and Güvercin 2018). Thus the consumption of renewable energy contributes both to environmental protection and to improving energy security. The use of renewable energy sources is also associated with the support of local economies, among others, by using local resources (Nada and Alrikabi 2014; Oztig 2017).

The energy sector is directly related to the use of natural resources, hence the need to adapt this sector to the principles of sustainable development. In this context, the goal of the energy policy should be to lead to the efficient use of resources and sustainable environmental behavior (Si et al. 2018). With regard to the concept of implementing sustainable development, the idea of sustainable energy has emerged, also called the sustainable energy mix. This term is identified primarily with the use of renewable energy sources. It can be defined as the production of electricity and heat and its distribution in accordance with the principles of sustainable development, i.e. in the least interfering with the natural environment and allowing the needs of present and future generations to be met. In order to implement the concepts of sustainable development, inexhaustible sources should be used in the production of energy, which pollute and degrade the environment as little as possible, the use of which does not pose a threat to health or do not involve social injustice (Prandecki 2014).

The production and consumption of renewable energy is currently one of the main pillars of the European Union's energy policy. The use of renewable energy enables achieving targets related to: the reduction of $\mathrm{CO}_{2}$ emissions and climate changes, improve energy efficiency and security (Saerbeck and Bianchi 2008; WEC 2014; Paska and Surma 2013). There are several variables defining the success of the renewables policy: the cost of the policy, the amount of renewable energy used and the speed of adoption of renewable energy. It is difficult to achieve all the goals at the same time. There is a need for trade-offs between the cost of politics, the speed of adoption and total implementation (Blazquez et al. 2018).

The 2020 climate and energy package is one of the most important tools of the European Union's energy policy. The package is intended as an example for other parts of the world in the fight against climate change and be the basis for a global climate agreement (Pach-Gurgul 2012).

\section{Research methods}

The research consists of two main stages. In the first stage the EU member states were divided into diversified classes according to the level of renewable energy sources consumption. The analysis was based on synthetic indicators - using a non-standard method. Synthetic indicators were assessed based on three features such as: the share of renewable energy in energy consumption in 2015, difference between the share of renewable energy in energy consumption in 
2015 and in 2005 (in percentage points), deficit/surplus in the 2020 target in 2015 (in percentage points). The data comes from Eurostat.

The research indicators are positively correlated with the level of renewable energy sources consumption. The selected features were normalized according to the stimulant formula (Wysocki and Lira 2003; Wysocki 2010). For each EU member state the synthetic indicator was determined as the average of normalized values (Wojciechowski and Wojtkowski 2015; Parysek and Wojtasiewicz 1979).

Based on the average $\left(q_{a}\right)$ and standard deviation $\left(S_{q}\right)$ of synthetic indicators EU member states were divided into four diversified classes (Wysocki and Lira 2003):

$\downarrow$ first class - a very high level (synthetic indicator values equal or higher than $q_{a}+S_{q}$ ),

$\checkmark$ second class - quite a high level - higher than average level (synthetic indicator values between $q_{a}+S_{q}$ and $q_{a}$ ),

$\downarrow$ third class - quite a low level - lower than average level (synthetic indicator values between $q_{a}$ and $\left.q_{a}-S_{q}\right)$,

$\downarrow$ fourth class - a very low level (synthetic indicator values below $q_{a}-S_{q}$ ).

In the second stage the divided classes were analyzed according to the share of renewable energy sources in the primary production of renewable energy and the consumption of individual renewable energy sources.

\section{Results}

The share of renewable energy in gross final consumption of energy in the researched years is presented in Figure 1. The target for 2020 varies from 10\% (Malta) to $49 \%$ (Sweden). The target is higher in countries that have been characterized by a significant share of RES in the structure of energy consumption for many years. Latvia, Finland and Sweden declared a target of more than $35 \%$, but in these countries the share of renewable energy in energy consumption exceeded $28 \%$ in 2005 . Member states where RES have not been very popular so far (less than $5 \%$ share in energy consumption in 2005), declared significantly lower target values (10-16\%). In the analyzed period, the share of RES in energy consumption increased in all the member states. However, the smallest changes (below 5 percentage points) concern countries with a relatively low share of RES in energy consumption (Luxembourg, Malta, Netherlands, Poland), the largest (over 10 percentage points) covered countries with a relatively large share of RES in energy consumption (Denmark, Estonia, Finland and Sweden). Italy and Hungary recorded a significant increase in this consumption (by 10 percentage points) despite the initially small share of renewable energy in energy consumption. It should be added that eleven member states have already achieved the target of renewable energy in total consumption. Six countries are characterized by a deficit of more than 5 percentage points (Belgium, Ireland, France, Luxembourg, the Netherlands and the United Kingdom) and in fact there is no possibility to achieve the target in 2020. 


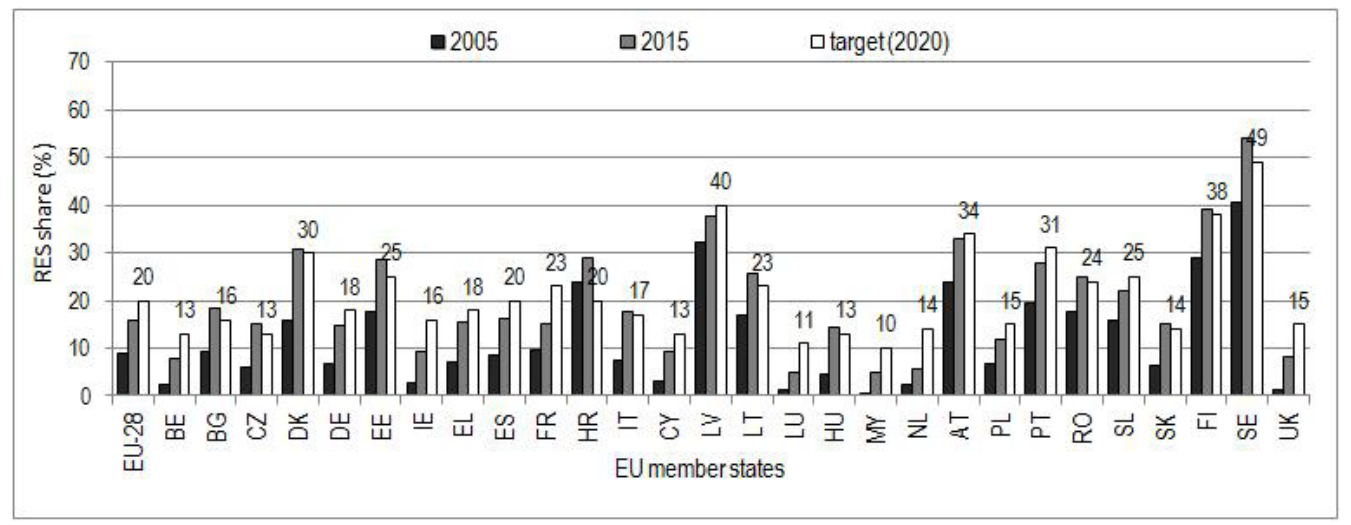

Fig. 1. The share of renewable energy in the gross final consumption of energy in European Union member states in 2005, 2015 and 2020 (target) [\%]

Source: own study based on Eurostat Database; Eurostat 2017

Rys. 1. Udział energii odnawialnej w konsumpcji energii w państwach Unii Europejskiej w latach 2005, 2015 i 2020 (cel wskaźnikowy) [\%]

Based on three researched features the synthetic level of RES consumption was designated for each of the member states. The European Union countries were divided into five classes with different levels of RES consumption. The results are presented in Table 1 and Figure 2. In addition, Table 2 contains data on the consumption of individual renewable energy sources in classes in 2005 and 2015.

The first class I includes four countries of Northern Europe (Denmark, Estonia, Finland, Sweden). These countries represent a very high level of renewable energy consumption. The values of diagnostic indicators significantly exceed European Union average values, confirming the very high level. In this class, the share of RES in energy consumption exceeds $38 \%$ and is twice as high as for the entire EU per one country. In the first class countries, the share of RES in consumption increased by more than 12 percentage points. All the first class countries exceeded the target in 2015 reaching a surplus of almost 3 percentage points per one country. In this class biomass dominates in RES consumption. According to the significant afforestation of first class countries, it is primarily forest biomass. Due to the shape of Sweden and Finland hydro energy is also quite important, and due to the seaside location - wind energy (especially in Denmark). It is worth adding that compared to 2005, most sources energy consumption increased - apart from geothermal energy. The hydro energy consumption increased slightly.

The second class consists of ten countries of Central and Eastern Europe (Bulgaria, Czech Republic, Latvia, Lithuania, Hungary, Romania), Southern Europe (Croatia, Italy, Portugal) and Austria. These countries represent quite a high level of renewable energy consumption. Diagnostic indicators are characterized by values higher than average in the European Union. In the second class the share of RES in energy consumption per 1 state slightly exceeds $24 \%$, and changes in this share in relation to 2005 exceed $8 \%$. In this group most of the countries have already reached the target in 2015. Latvia, Austria and Portugal are an exception, but the targets of these 


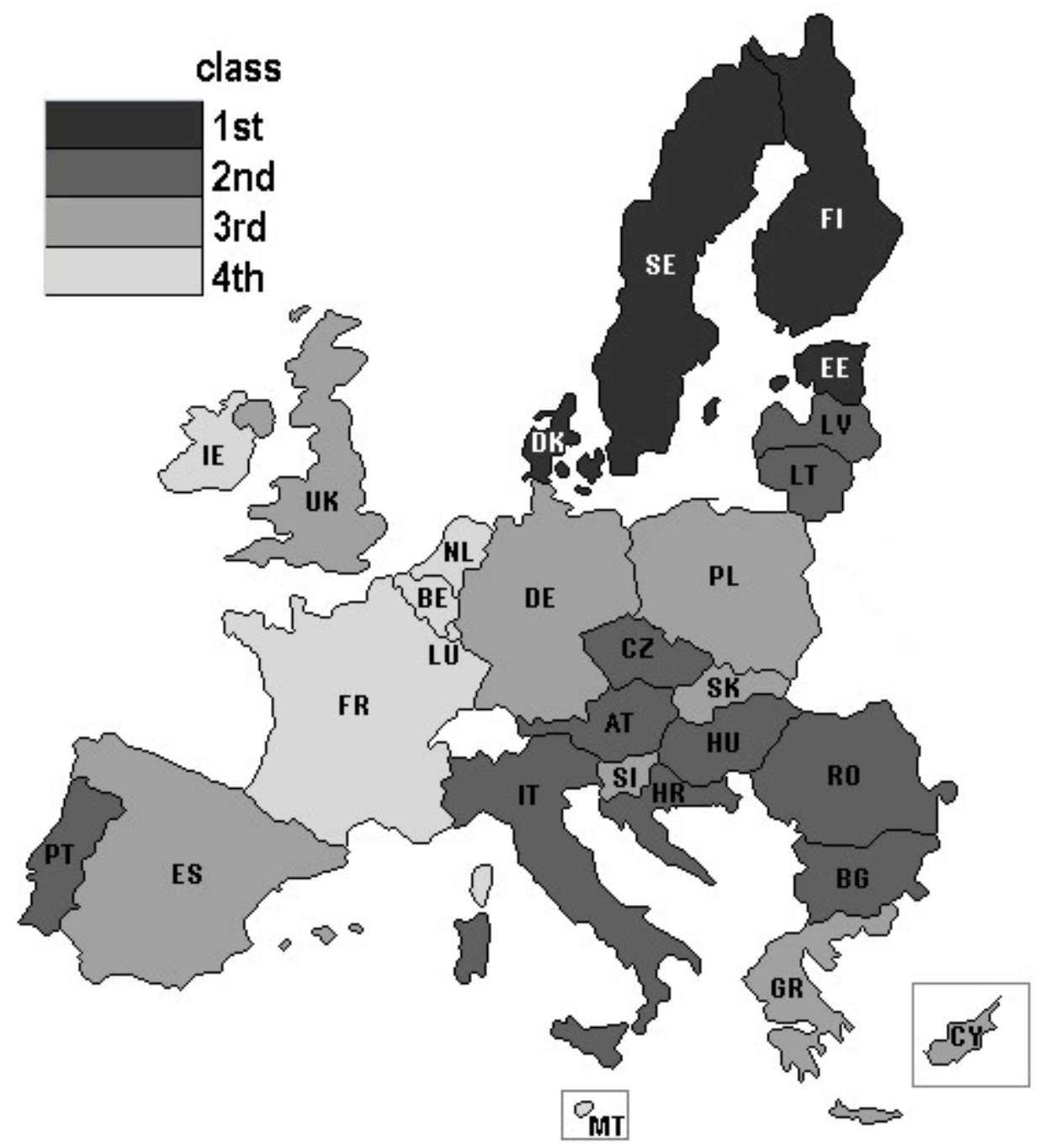

Fig. 2. Diversification of renewable energy sources consumption in EU member states

Source: own study based on Eurostat Database; Eurostat 2017

Rys. 2. Zróżnicowanie konsumpcji energii ze źródeł odnawialnych w państwach UE

countries are high $(40,34,31 \%$ respectively). Similarly to the first class I, biomass dominates in renewable energy consumption in the second class countries. Due to the conditions of these areas, it is mostly agricultural biomass. Water is another significant source of renewable energy. The landform of countries allows the use of this type of energy in the second class member states. In addition, in the second class the greatest importance of geothermal energy in the renewable energy consumption was recorded among the analyzed classes (due to the presence of Italy in this class). During the researched period, the largest increase in RES consumption in the second class 
TABLE 1. Diversification of renewable energy sources consumption in EU member states researched features

TABELA 1. Zróżnicowanie konsumpcji energii ze źródeł odnawialnych w państwach UE - badane cechy

\begin{tabular}{|l|c|c|c|c|c|}
\hline \multicolumn{1}{|c|}{ Specification } & $1^{\text {st }}$ class & $2^{\text {nd }}$ class & $3^{\text {rd }}$ class & $4^{\text {th }}$ class & Total \\
\hline $\begin{array}{l}\text { Share of renewable energy in energy } \\
\text { consumption in 2015 [\%] }\end{array}$ & 38.15 & 24.35 & 13.81 & 8.02 & 19.81 \\
\hline $\begin{array}{l}\text { Difference between share of renewable energy } \\
\text { in energy consumption in 2015 and in 2005 } \\
\text { (in percentage points) }\end{array}$ & 12.43 & 8.14 & 6.84 & 4.88 & 7.68 \\
\hline $\begin{array}{l}\text { Deficit/ surplus the 2020 target in 2015 } \\
\text { (in percentage points) }\end{array}$ & 2.65 & 1.25 & -3.44 & -6.48 & -1.55 \\
\hline Synthetic indicator & 0.70 & 0.46 & 0.25 & 0.10 & 0.36 \\
\hline
\end{tabular}

Source: own study based on Eurostat Database; Eurostat 2017.

TABLE 2. Renewable energy sources consumption in EU member states in 2005 and 2015

TABELA 2. Konsumpcja energii ze źródeł odnawialnych w państwach UE w latach 2005 i 2015

\begin{tabular}{|c|c|c|c|c|c|c|c|c|c|c|}
\hline \multirow{2}{*}{ Specification } & \multicolumn{2}{|c|}{$1^{\text {st }}$ class } & \multicolumn{2}{|c|}{$2^{\text {nd }}$ class } & \multicolumn{2}{|c|}{$3^{\text {rd }}$ class } & \multicolumn{2}{|c|}{$4^{\text {th }}$ class } & \multicolumn{2}{|c|}{ EU total } \\
\hline & 2005 & 2015 & 2005 & 2015 & 2005 & 2015 & 2005 & 2015 & 2005 & 2015 \\
\hline \multicolumn{11}{|c|}{ Mtoe/10,000 inhabitants } \\
\hline RES total & 9.30 & 11.85 & 6.10 & 10.40 & 2.71 & 5.05 & 1.73 & 3.72 & 4.65 & 7.65 \\
\hline Biomass & 6.70 & 8.49 & 3.42 & 6.29 & 1.67 & 2.72 & 1.28 & 2.30 & 2.93 & 4.73 \\
\hline Hydro & 2.30 & 2.32 & 1.44 & 1.63 & 0.63 & 0.74 & 0.27 & 0.29 & 1.08 & 1.18 \\
\hline Wind & 0.29 & 0.99 & 0.08 & 0.54 & 0.28 & 0.83 & 0.16 & 0.94 & 0.18 & 0.77 \\
\hline Biogas & 0.07 & 0.16 & 0.10 & 0.61 & 0.10 & 0.30 & 0.10 & 0.21 & 0.09 & 0.37 \\
\hline Solar & 0.01 & 0.04 & 0.02 & 0.61 & 0.11 & 0.74 & 0.01 & 0.18 & 0.04 & 0.47 \\
\hline Geothermal & 0.00 & 0.00 & 1.14 & 1.33 & 0.01 & 0.04 & 0.01 & 0.01 & 0.41 & 0.49 \\
\hline \multicolumn{11}{|c|}{$\%$} \\
\hline Biomass & 72.01 & 71.67 & 56.08 & 60.48 & 61.79 & 53.84 & 73.93 & 61.80 & 63.00 & 61.85 \\
\hline Hydro & 24.76 & 19.58 & 23.63 & 15.67 & 23.29 & 14.65 & 15.68 & 7.79 & 23.26 & 15.43 \\
\hline Wind & 3.14 & 8.36 & 1.27 & 5.19 & 10.40 & 16.43 & 9.14 & 25.26 & 3.95 & 10.07 \\
\hline Biogas & 0.76 & 1.35 & 1.64 & 5.87 & 3.58 & 5.94 & 5.61 & 5.64 & 2.03 & 4.84 \\
\hline Solar & 0.07 & 0.34 & 0.34 & 5.87 & 4.24 & 14.65 & 0.71 & 4.84 & 0.94 & 6.15 \\
\hline Geothermal & 0.02 & 0.00 & 18.61 & 12.79 & 0.28 & 0.79 & 0.45 & 0.27 & 8.80 & 6.41 \\
\hline
\end{tabular}

Source: own study based on Eurostat Database; Eurostat 2017.

(Mtoe per 10,000 inhabitants) was observed, mainly due to biomass. The share of biomass in the structure of RES consumption increased between 2005 and 2015 - this is the only such class.

The third class includes six countries of Central Europe (Poland, Slovakia, Slovenia), Southern Europe (Greece, Spain, Cyprus) and Western Europe (Germany and Great Britain). 
These countries are characterized by quite a low level of renewable energy consumption. The values of diagnostic indicators are lower than the European Union average. In the third class the share of RES in energy consumption did not exceed $14 \%$ per one country, and changes compared to 2005 did not exceed $7 \%$. None of the third class countries has yet reached the target. This situation caused a negative value of the third diagnostic indicator. In the third class, biomass is important in the renewable energy consumption, although its share dropped in favor of wind and solar energy in the studied years. Due to the climate, the Southern Europe countries use the energy of the sun, coastal countries - wind energy and mountainous countries - hydro energy.

The fourth class consists of six countries. these are mainly Western European countries (Belgium, Ireland, France, Luxembourg, Malta, Netherlands). The fourth class states are characterized by the lowest level of RES consumption. The share of RES in energy consumption is $8 \%$ per one country in the fourth class. In the analyzed period changes in the share of RES in energy consumption did not exceed $5 \%$ per country. In the fourth class countries, the largest deficit of the target was recorded. The deficit value exceeded $6 \%$ per one country. Energy consumption increased according to all the analyzed renewable energy sources, However, the current growth of the RES share in energy consumption will not allow the target to be achieved in 2020. Among the renewable energy sources, agricultural biomass is mainly used in fourth class countries (Benelux and France). Wind power is also important (Ireland). In relation to 2005, the importance of hydro energy decreased in favor of wind energy.

\section{Discussion}

The European Union stands out positively in terms of a more environmentally friendly and climate-friendly energy policy. In the European Union member states renewables are important energy sources (EC 2015). However, individual European Union countries differ due to the level of renewable energy sources consumption. This situation results from various conditions (including natural), as well as a different energy mix developed over the years at the national level.

The increase of the renewable energy consumption means the decrease of conventional fuels consumption, recently widely used. Changes in the structure of production and consumption of energy cover a long-term and complicated process. This is a particularly difficult process for countries that are basing their energy policy on conventional fuels, including Central and Eastern Europe countries. Countries of Northern and Western Europe are considered more pro-environmental, also in the use of renewable energy sources (Fischer 2014; Ringel and Knodt 2018). However, the countries of Central and Eastern Europe systematically complement long-term arrears in renewable energy production and consumption (Reuter et al. 2017). According to the results of the presented research, Northern Europe is characterized by the highest level of renewable energy consumption. Central and Eastern European countries are mostly characterized by quite 
a high level of renewable energy consumption. The position of the Western European Countries is much lower. These countries have been included in the third and fourth class. The European Commission noted the unfavorable situation of France, Luxembourg and Netherlands in their report (EC 2017).

Biomass is the most popular renewable energy source in the European Union, also according to the results of the presented analyses. It is both agricultural and forest biomass due to the conditions of individual countries - the agricultural function of most European Union countries and the forestry function of Northern Europe countries (Janiszewska and Ossowska 2016; Janiszewska and Ossowska 2015; Ossowska and Janiszewska 2016). A further increase in the importance of agricultural and forest biomass is expected in the future. This situation results both from the need to achieve RES targets as well as the necessity of waste management (Pudełko 2013). According to the presented results, the volume of consumed biomass energy increased between 2005 and 2015, whereas the share of biomass decreased slightly in the consumption structure. This should be considered a positive development because the diversification of energy sources is needed. According to Pach-Gurgul (2012) the diversification of energy sources and the rational management of energy resources form the basis of EU energy security.

\section{Conclusions}

According to the research aim, the diversification of renewable energy sources consumption in the EU member states was discussed and assessed in the presented article. RES consumption increased between 2005 and 2015 in the European Union the - both the total RES consumption as well as the individual sources of energy consumption. However, due to the level of RES consumption, individual countries are characterized by a diverse situation.

According to the results of the presented research, Northern Europe is characterized by the highest level of renewable energy consumption. Central and Eastern Europe is mostly characterized by a quite high level of renewable energy consumption. The position of the Western European countries is much lower. These countries mostly represent quite a low and a low level of RES consumption.

The increase of the renewable energy consumption means the decrease of conventional fuels consumption. Changes in the structure of the production and consumption of energy cover a long-term and complicated process - especially for countries that base their energy policy on conventional fuels.

Biomass is the most popular renewable energy source in the European Union. Depending on the conditions of individual countries - it is agricultural and forest biomass. The individual member states differ in the dynamics of the energy policy implementation. However, the necessity to achieve the RES target contributes to changes in energy production and consumption in European Union countries. 


\section{References}

BlAzQueZ et al. 2018 - BlAZqueZ, J. NEZAMUdDin, N. and ZAMrIK, T. 2018. Economic policy instruments and market uncertainty: Exploring the impact on renewables adoption. Renewable and Sustainable Energy Reviews 94, pp. 224-233.

CIECHANOWICZ, W. 1997. Energy, environment and economy (Energia, środowisko i ekonomia). Warszawa: PAN, p. 13.

EC 2010. Communication from the Commission to the European Parliament, the Council, the European Economic and Social Committee and the Committee of the Regions Energy 2020 A strategy for competitive, sustainable and secure energy (COM/2010/0639 final).

EC 2011. World and European Energy and Environment Transition Outlook. Studies and Reports. Brussels: European Commission, pp. 64-69.

EC 2015. The European Union leading in renewables. COP21. Brussels: European Commission, pp. 1-28.

EC 2017. Renewable Energy Progress Report 56, Brussels: European Commission, p. 10.

Eurostat 2017. Energy, transport and environment indicators. 2017 edition. Luxembourg: Publications Office of the European Union, p. 51.

Eurostat Database. [Online] http://ec.europa.eu/eurostat/data/database [Accessed: 2019-01-25].

FISCHER, S. 2014. The EU's new energy and climate: policy framework for 2030. SWP Comments 55, pp. $1-8$.

FRIDLEIFSSON, I.B. 2001. Geothermal energy for the benefit of the people. Renewable and Sustainable Energy Reviews 5, pp. 299-312.

GÖKGÖZ, F. and GÜVERCIN, M.T. 2018. Energy security and renewable energy efficiency in EU. Renewable and Sustainable Energy Reviews 96, pp. 226-239.

IJADI MAGHSOODI et al. 2018 - IJADI MAGHSOODI, A. IJADI MAGHSOODI, A. MOSAVI, A. RABCZUK, T. and ZAVADSKAS, E.K. 2018. Renewable Energy Technology Selection Problem Using Integrated H-SWARA-MULTIMOORA Approach. Sustainability 10, pp. 4481-4498.

JABŁOŃSKI, W. and WNUK, J. 2009. Management of renewable energy sources. Economic and technical aspects (Zarzadzanie odnawialnymi źródłami energii. Aspekty ekonomiczno-techniczne). Sosonowiec: Humanitas Publishing House, p. 29 (in Polish).

JANISZEWSKA, D. and OSSOWSKA, L. 2015. Diversification of agricultural conditions for the production of renewable energy from biomass in European Union countries (Zróżnicowanie uwarunkowań rolnictwa dla produkcji energii odnawialnej z biomasy w krajach Unii Europejskiej). Problemy Rolnictwa Światowego 15(2), pp. 75-84 (in Polish).

JANISZEWSKA, D. and OSSOWSKA, L. 2016. Diversification of agricultural functions in the European Union countries based on selected features (Zróżnicowanie funkcji rolniczej w krajach Unii Europejskiej na podstawie wybranych cech). Problemy Rolnictwa Światowego 16(2), pp. 134-144 (in Polish).

Kościk, B. 2012. Legal regulations in the field of renewable energy sources (Regulacje prawne w zakresie odnawialnych źródel energii). [In:] Kołodziej, B. and Matyka, M. ed. Renewable energy sources in Poland. Agricultural energy resources (Odnawialne źródta energii w Polsce. Rolnicze surowce energetyczne). Poznań: PWRiL, p. 50.

MiciUŁA, I. 2015. Energy policy of the European Union until 2030 as part of sustainable development (Polityka energetyczna Unii Europejskiej do 2030 roku w ramach zrównoważonego rozwoju). Studia i Prace Wydziału Nauk Ekonomicznych i Zarządzania, Wydawnictwo Uniwersytetu Szczecińskiego 42(2), pp. 57-67 (in Polish).

NaDA, Kh. and AlriKaBi M.A. 2014. Renewable Energy Types. Journal of Clean Energy Technologies 2(1), pp. 61-64. 
OsSOWSKA, L. and JANISZEWSKA D. 2016. Diversity of forest functions in European Union countries (Zróżnicowanie funkcji lasów w krajach Unii Europejskiej). Problemy Rolnictwa Światowego 16(3), pp. 292-300 (in Polish).

OzTIG, L.I. 2017. Europe's climate change policies: The Paris Agreement and beyond. Energy Sources Part B 12(10), pp. 917-924.

PACH-Gurgul, A. 2012. The single electricity market in the European Union in the context of Poland's energy security (Jednolity rynek energii elektrycznej w Unii Europejskiej w kontekście bezpieczeństwa energetycznego Polski). Warszawa: Difin, pp. 82-98 (in Polish).

PACH-Gurgul, A. 2014. Renewable energy of the European Union in the conditions of economic crisis (Energetyka odnawialna Unii Europejskiej w warunkach kryzysu gospodarczego). Prace Komisji Geografii Przemystu Polskiego Towarzystwa Geograficznego 27, p. 138 (in Polish).

PANWAR et al. 2011 - PANWAR, N.L. KAUShIK, S.C. and Kothari, S. 2011. Role of renewable energy sources in environmental production: A review. Renewable and Sustainable Energy Reviews 15, pp. 1513-1524.

PARYSEK, J. and WoJTASIEWICZ, L. 1979. Methods of regional analysis and methods of regional planning (Metody analizy regionalnej i metody planowania regionalnego). Warszawa: PWN, pp. 25-26 (in Polish).

PASKA, J. and Surma, T. 2013. The energy policy of Poland against the background of the European Union's energy policy (Polityka energetyczna Polski na tle polityki energetycznej Unii Europejskiej). Energy Policy Journal 16(4), pp. 7-19 (in Polish).

PRANDECKI, K. 2014. Theoretical foundations of sustainable energy (Teoretyczne podstawy zrównoważonej energetyki). Studia Ekonomiczne 166, pp. 238-241 (in Polish).

PudeŁKo, R. 2013. Assessment of the potentials of side and waste biomass in the EU-27 and Switzerland and their regionalization (Ocena potencjałów biomasy ubocznej i odpadowej w UE-27 I Szwajcarii oraz ich regionalizacja). Puławy: IUNG-PIB, p. 154 (in Polish).

Reuter et al. 2017 - Reuter, M. PATEl, M.K. and EICHHAMmer, W. 2017. Applying ex-post index decomposition analysis to primary energy consumption for evaluating progress towards European energy efficiency targets. Energy Efficiency 6, pp. 1381-1400.

RingeL, M. and KNODT, M. 2018. The governance of the European Energy Union: efficiency, effectiveness and acceptance of the Winter Package 2016. Energy Policy 112, pp. 209-220.

SAERBECK, R. and BiAnCHI, M. 2008. Evaluation of renewable energy. Projects in Europe. Synthesis Report, p. 1.

Si et al. 2018 - SI, S. LYU, M. LIN LAWELL, C-Y.C. and CHEN, S. 2018. The effects of energy-related policies on energy consumption in China. Energy Economics 76, pp. 202-227.

WEC 2014. Climate Change: Implications for the Energy Sector. Fifth Assessment Report. University of Cambridge: World Energy Council, p. 4.

WOJCIECHOWSKI, S. and WOJTKOWSKI, D. 2015. Methodology and research results (Metodologia $i$ wyniki badań). [In:] Woźniak, K. ed. Analytical tools in economic sciences (Narzędzia analityczne w naukach ekonomicznych). Kraków: Mfiles, p. 111.

WoJTKOWSKA-ŁODEJ, G. 2014. Climatic and energy challenges and the European Union's policy (Wyzwania klimatyczne i energetyczne a polityka Unii Europejskiej). Energy Policy Journal 17(2), pp. 39-52 (in Polish).

WYSOCKI, F. 2010. Taxonomic methods in recognizing economic types of rural agriculture (Metody taksonomiczne w rozpoznawaniu typów ekonomicznych rolnictwa obszarów wiejskich). Poznań: Uniwersytet Przyrodniczy w Poznaniu, pp. 151-152 (in Polish).

WysOcKI, F. and LIRA, J. 2003. Descriptive statistics (Statystyka opisowa). Poznań: Wydawnictwo AR w Poznaniu, pp. 173-175 (in Polish). 


\title{
Konsekwencje polityki energetycznej w państwach Unii Europejskiej - cele w zakresie odnawialnych źródeł energii
}

\author{
Streszczenie
}

Celem artykułu jest omówienie i ocena zróżnicowania konsumpcji odnawialnych źródeł energii w państwach członkowskich UE. Zakres czasowy obejmuje 2005 i 2015 rok. Dane pochodzą z Eurostatu. Analizę przeprowadzono w oparciu o syntetyczny miernik rozwoju, używając metody bezwzorcowej. Miernik syntetyczny wyznaczono na podstawie trzech cech prostych: udział odnawialnych źródeł energii w konsumpcji energii w 2015 roku, różnica udziału energii odnawialnej w konsumpcji energii pomiędzy 2005 a 2015 rokiem (w punktach procentowych), deficyt/nadwyżka w zakresie osiągnięcia w 2015 roku celu wskaźnikowego wyznaczonego na 2020 rok (w punktach procentowych). Państwa UE zostały podzielone na cztery grupy zróżnicowane pod względem konsumpcji odnawialnych źródeł energii (pierwsza klasa - bardzo wysoki poziom, druga klasa - wysoki poziom, trzecia klasa - dość niski poziom, czwarta klasa - bardzo niski poziom). Następnie podzielone grupy zostały przeanalizowane pod kątem udziału odnawialnych źródeł energii w pierwotnej produkcji energii odnawialnej i zużycia poszczególnych odnawialnych źródeł energii. W badanym okresie zużycie energii z OZE wzrosło w Unii Europejskiej, ale poszczególne państwa członkowskie charakteryzują się zróżnicowaną sytuacją. Rodzaj wykorzystywanej energii w dużej mierze zależy od zasobów krajowych. Większym udziałem odnawialnych źródeł energii w konsumpcji charakteryzują się kraje Europy Północnej. Najpopularniejszym odnawialnym źródłem energii w krajach Unii Europejskiej jest biomasa. W zależności od warunków poszczególnych krajów - jest to biomasa rolnicza i leśna.

SŁoWA KLUCZOWE: polityka energetyczna, energia odnawialna, państwa Unii Europejskiej 